\title{
Information Management Training
}

\author{
Adeline du Toit \\ asadt@lw.rau.ac.za
}

Business intelligence, also referred to as corporate or competitive intelligence, is an emerging discipline that has become increasingly important in the business arena since the early 1980s. Although its practical origins date back many decades, its intellectual origins can be attributed to Harvard professor, Michael Porter, when in 1980 he used the technique of competitive intelligence to analyse industries and competitors. A possible explanation for this emerging discipline is the information explosion characterized by the increasing availability of information itself, as reflected in the proliferation of commercial databases worldwide. Other causes of this growth are possibly the very nature of the times in which we now live - times of great worldwide political and social changes, the increasing pace of business, increased global competition from new competitors, more aggressive competition and rapid technological changes.

Cognos Business Intelligence University (BIU) is a unique programme designed to teach decision makers how to positively impact the bottom line by using business intelligence solutions for strategic and daily decision making across the enterprise. At BIU, multidimensional managers take ownership of their results - it is their analysis and decision making, supported by business intelligence solutions, which grow revenues and drive down costs. Ultimately, the experience underscores the profit opportunity when a business operates as a coordinated enterprise where organizational speed and effectiveness are enhanced by linking and sharing key performance metrics across functional silos.

BIU is an executive MBA-like course that teaches business process management theory such as the use of key performance indicators (KPI) and balanced scorecards through the use of business intelligence tools.

'Over the last two years, hundreds of senior executives from enterprises such as Johnson and Johnson, Pfizer, Price Waterhouse Coopers, Timberland, and the US Navy have attended BI University', states Alan Rottenberg, Cognos' Senior Vice President, Marketing and Business Strategy.

Cognos announced on 31 October 2002 that it has received the highest ranking in the SPEX comparative business intelligence product review. Receiving an 'outstanding' designation from SPEX, a division of META Group, Cognos was tested for functionality, usability, and overall technology and market strength along with seven leading business intelligence solutions, including Crystal, Brio, MicroStrategy, Hyperion, IBI and Actuate.

In South Africa, PQ Business Intelligence, a division of Q Data Consulting, has been appointed to run Cognos' Business Intelligence University (BIU). PQ Business Intelligence (PQBI) runs the two-day course every two months in Cape Town and Johannesburg.

Participation in the class is limited to 16 students, who are divided into four teams of four, 
with the teams effectively competing with each other.

Students employ Cognos' 24 Best Practices to coordinate decisions across marketing, sales, purchasing, production, distribution, customer service, human resources and administration, and information technology. Each team submits its decisions and observes their impact on each of four fiscal quarters. This allows students to experience first-hand the effects of their decisions on the bottom line.

Further information contact Gill Staniland at 0824522076 or visit the Cognos Web site at www.cognos.com.

\section{Disclaimer}

Articles published in SAJIM are the opinions of the authors and do not necessarily reflect the opinion of the Editor, Board, Publisher, Webmaster or the Rand Afrikaans University. The user hereby waives any claim he/she/they may have or acquire against the publisher, its suppliers, licensees and sub licensees and indemnifies all said persons from any claims, lawsuits, proceedings, costs, special, incidental, consequential or indirect damages, including damages for loss of profits, loss of business or downtime arising out of or relating to the user's use of the Website.

ISSN 1560-683X

Published by InterWord Communications for the Centre for Research in Web-based Applications, Rand Afrikaans University 